\title{
ESP Teaching Practice and Exploration on TBLT Method
}

\author{
Bo Du ${ }^{a}$, Jing Zhang ${ }^{b}$, Yan Zhang ${ }^{c}$ \\ Foreign Languages College of Agricultural University of Hebei, Baoding 071001, China \\ aDuBo80@126.com, b1301683942@qq.com, cLdmmail@163.com
}

\begin{abstract}
With the rapid economic development and the increasingly deep opening to the outside world in China, international exchanges and cooperation has been becoming more frequent, so our country need compound talents who have mastered not only professional competence but also English. ESP teaching aimed to practical talent cultivation and stressed the students' language practical ability. This paper took Business English Writing for example, used TBLT (task-based language teaching) method to do the implementation and investigation, and explored the compound talents training pattern in the ESP theory.
\end{abstract}

Keywords: ESP Teaching; TBLT; Compound Talents.

\section{Introduction}

ESP (English for Specific Purposes) is associated with certain professions and academic disciplines, which is set up in accordance with the specific needs of the learners. Under the different professions many colleges and universities set up ESP teaching; such as Tourism English, Hotel English, Business English, so that students were able to read the professional English documents and exchange with foreign technical personnel directly. But the effect was not satisfactory.

At present, ESP generally used PPP mode, namely, presentation, practice, and production. This model was a typical teacher-centered, that meant teachers said, students listened, accumulated a certain amount of knowledge through a lot of practice after-school and completed some static examination indicators, and students in the classroom were completely passive audience. Taking Business English Writing for example, I changed the traditional teaching methods and used TBLT to do ESP teaching practice and exploration.

\section{Application Survey of TBLT in Business English Writing}

I selected Economics students as experimental subjects to have Business English Writing courses using TBLT method. Specific steps are as follows:

\subsection{The Knowledge Bedding}

First a brief introduction about the content in this chapter was made, which included some concepts, terminology and common sense related to Business English Writing, such as the introduction of a sales promotion letter, order letter, complaint letter. The students were divided into four study groups; each would have a lecture to the class in English focusing on the contents of this section.

\subsection{Independent Learning}

In order to complete the task, students would take great initiative in reading the content of Business English Writing, gathering the task-related data carefully and asking the teacher for help when necessary. In this part the students' independent learning enabled them to further understand and master the relevant knowledge of Business English Writing, and to lay a solid foundation for subsequent discussion in groups. The role of teachers was changed from the authority in the traditional classroom to the designer and organizer of the task, and facilitator of learning. The students' independent learning has been developed and strengthened in this process.

\subsection{Group Learning and Discussion}

After learning Business English Writing terminology and understanding the relevant professional background, it was easy for students to complete the task that the teacher design, such as group discussions, paired exercises and classroom presentation in English. In this process the whole class 
was split into multiple groups to create opportunities of practice for each student to the full extent and to avoid the previous phenomenon that a few students always spoke actively while most of them just stood on the sidelines and watched. Because of the uneven English proficiency of students, teachers shouldn't stick to the students' language forms and grammatical errors, but should emphasize the significance of the task and encourage students to participate actively in English class.

It should be noted that in the process of independent learning and group discussion only when the students need help, should teachers intervene timely; for example, teachers should give some suggestions, hints or answers when students had questions or problems.

\subsection{Summarize and Report}

The study group should give lectures to the class in English around the contents of this section. In order to explain lively, thoroughly, and interestingly, the ppt courseware could be used. Judging from what the students complete, the contents were wonderful and slides also had their own characteristics, including sound files, image files, audio and video materials.

In the process of implementation and completion of tasks, there were a lot of opportunities for the students to use oral English, so it was inevitable to appear Chinese English. Although teacher encouraged students to discuss in the target language, in order to prevent the language forms being damaged, it was necessary for teacher to summarize follow-up stage of a mission.

\section{The Comparative Analysis of TBLT and Traditional Teaching Methods}

In the same period I used the traditional teaching methods in another class of the same major; the two class opened same courses, so they were comparable. After the end of the course, I also designed a questionnaire survey; 120 questionnaires were released in two classes and 116 effective were recalled. The problems was divided into four levels: learning the course did not harvest, small, large, great; students select the appropriate $0,1,2$, 3. Comparative survey is as Table1.

Table 1 Comparative Survey between TBLT Method and Traditional Teaching Method

Questionnaire Items $\quad$ TBLT method average scores
1.87

2.03

1.61

1.32

1.95

\subsection{Cultural Background Knowledge}

The teacher arranged for a series of tasks according to the principle of TBLT. Students in groups collected task-related information and produced classroom display electronic documents after school; in that process students took the initiative to learn the language and understand the language and cultural background. On the contrary, in traditional classroom the teacher explained cultural knowledge and students received passively; the scope of the knowledge and classroom time was limited by the teacher. Therefore in the cultural background TBLT was far higher than traditional teaching methods.

\subsection{Reading Ability and Oral English}

In TBLT practice, students need to read a huge mass of data to get useful information and then read the valid data detailedly so that arranged for classroom display material; meanwhile the students organized their classroom display language. Students read authentic language materials and 
increased the opportunity for oral expression, and they were changed from passive acceptance to active participation.

\subsection{English Language Knowledge}

The score of TBLT was lower than traditional teaching methods in language knowledge. This was mainly because most of the students thought that traditional teaching methods taught the basic knowledge of language, language point, and text structure knowledge; While in TBLT those knowledge need to be leaned by themselves. Some students were somewhat at a loss, because they were accustomed to teacher-centered mode of knowledge transfer.

Secondly, another reason was that when some students encountered the difficult problem of English language, they would use Chinese alternative, which weakened the English language learning and use to some extent. Therefore, the teachers' classroom summary and after-school examination was necessary.

\subsection{Collaboration and Self-confidence}

Read from the table, the score of TBLT about collaboration was far higher than traditional teaching methods. TBLT provided a platform for collaboration and requirements which traditional teaching did not have. In the investigation most of the students, from small to large, had accepted the traditional education model; they always completed the task independently, rarely in small groups. Group activities in TBLT provided a platform, where their talents and hobbies could be displayed. Subsequently, students strengthened their self-confidence and improved their learning interests, and demonstrated their own learning was a kind of self-confidence consciousness exercise and test. It was certain that self-confidence score in TBLT was higher than the traditional English teaching methods.

\section{Conclusion}

In summary, either from the perspective of individual needs or the needs of the community, ESP teaching practice can meet the demand of English learning from singularity to the diversity. Compared with the traditional mode of teaching, TBLT that took into account students' knowledge of language learning and emphasized on the content of their professional input was more suitable for the talent requirements of modern society. But there was still insufficient in practice. Only by constantly exploring and summarizing is the college English teaching reform more effective and more qualified compound talents trained for the community.

\section{Acknowledgements}

This paper is one of the initial results of Hebei Province Human Resources and Security Department general project "Strengthening ESP Compound Talents Training in the Agricultural Colleges" (JRS has-2012-3011).

\section{References}

[1]. Maclntyre, P. Toward a social psychological mode of strategy use. Foreign language annuals. Vol.27 (1994), p.185-195.

[2]. Dudley-Evans, Tony. Developments in English for Specific Purposes: A multi-disciplinary approach. Cambridge: Cambridge University Press, 1998, p.4-5.

[3]. Song, B. Content-based ESL instruction: Long-term effects and outcomes. English for Specific Purposes. Vol.25 (2006), p.420-437.

[4]. CAI Ji-gang. ESP and the direction of China s college English teaching. Foreign Language World. Vol.2 (2004), p.22-28.

[5]. CAI Ji-gang. A Study of Discipline-based English from the Perspective of CBI. Foreign Language Education. Vol.05 (2011), p.39-42.

[6]. GAO Zhan-rong. The Inspiration of ESP Teacher Education abroad for the Knowledge Development of College English Teachers in China. Studies in Foreign Education. Vol.4 
(2012), p.85-91.

[7]. ZHU Xiao-hua. Curriculum and teaching of the course, Hotel English from the perspective of ESP: a case study. Journal of Chongqing Education College. Vol.1 (2012), p.151-154, 172.

[8]. Beson, P. Teaching and researching autonomy in language learning. Beijing, China: Foreign Language Teaching and Research Press, 2005, p.56-59.

[9]. Liu Yu. The training of ESP learning strategies under the analysis of demand. Journal of Nanchang College of Education. Vol.26(2011), No.10, p.155-157

[10]. Peng Yan. Task-based Method in Teaching of ESP Reading. Journal of Civil Aviation Flight University of China. Vol.23 (2012), No.2, p.74-77.

[11]. HOU Xiao-dan, MA Yong-liang, GAO Ting-ting. Learning Needs Analysis of Diverse ESP English Courses for Non-English Majors--- An Empirical Study of College English Curriculum Reform about the Transition from EGP to ESP. Journal of Dalian University. Vol.35 (2014), No.3, p.141-144. 